\title{
Front Matter: Volume 10334
}

, "Front Matter: Volume 10334," Proc. SPIE 10334, Automated Visual Inspection and Machine Vision II, 1033401 (7 September 2017); doi: 10.1117/12.2284245

SPIE. Event: SPIE Optical Metrology, 2017, Munich, Germany 


\section{PROCEEDINGS OF SPIE}

\section{Automated Visual Inspection and Machine Vision II}

Jürgen Beyerer

Fernando Puente León

Editors

29 June 2017

Munich, Germany

Sponsored by

SPIE

Cooperating Organisations

European Optical Society

German Scientific Laser Society (Wissenschaftliche

Gesellschaft Lasertechnik e.V.)

Published by

SPIE 
The papers in this volume were part of the technical conference cited on the cover and title page. Papers were selected and subject to review by the editors and conference program committee. Some conference presentations may not be available for publication. Additional papers and presentation recordings may be available online in the SPIE Digital Library at SPIEDigitalLibrary.org.

The papers reflect the work and thoughts of the authors and are published herein as submitted. The publisher is not responsible for the validity of the information or for any outcomes resulting from reliance thereon.

Please use the following format to cite material from these proceedings:

Author(s), "Title of Paper," in Automated Visual Inspection and Machine Vision II, edited by Jürgen Beyerer, Fernando Puente León, Proceedings of SPIE Vol. 10334 (SPIE, Bellingham, WA, 2017) Seven-digit Article CID Number.

ISSN: 0277-786X

ISSN: 1996-756X (electronic)

ISBN: 9781510611139

ISBN: 9781510611146 (electronic)

Published by

SPIE

P.O. Box 10, Bellingham, Washington 98227-0010 USA

Telephone +1 3606763290 (Pacific Time) · Fax +1 3606471445

SPIE.org

Copyright (c) 2017, Society of Photo-Optical Instrumentation Engineers.

Copying of material in this book for internal or personal use, or for the internal or personal use of specific clients, beyond the fair use provisions granted by the U.S. Copyright Law is authorized by SPIE subject to payment of copying fees. The Transactional Reporting Service base fee for this volume is $\$ 18.00$ per article (or portion thereof), which should be paid directly to the Copyright Clearance Center (CCC), 222 Rosewood Drive, Danvers, MA 01923. Payment may also be made electronically through CCC Online at copyright.com. Other copying for republication, resale, advertising or promotion, or any form of systematic or multiple reproduction of any material in this book is prohibited except with permission in writing from the publisher. The CCC fee code is 0277$786 \mathrm{X} / 17 / \$ 18.00$.

Printed in the United States of America.

Publication of record for individual papers is online in the SPIE Digital Library.

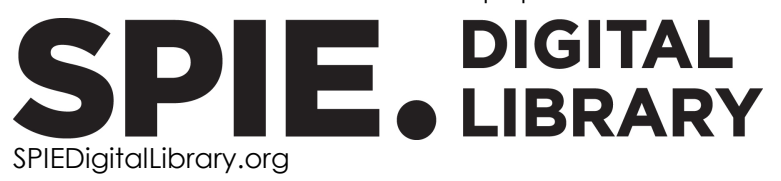

Paper Numbering: Proceedings of SPIE follow an e-First publication model. A unique citation identifier (CID) number is assigned to each article at the time of publication. Utilization of CIDs allows articles to be fully citable as soon as they are published online, and connects the same identifier to all online and print versions of the publication. SPIE uses a seven-digit CID article numbering system structured as follows:

- The first five digits correspond to the SPIE volume number.

- The last two digits indicate publication order within the volume using a Base 36 numbering system employing both numerals and letters. These two-number sets start with $00,01,02,03$, 04, 05, 06, 07, 08, 09, 0A, OB ... 0Z, followed by 10-1Z, 20-2Z, etc. The CID Number appears on each page of the manuscript. 


\title{
Contents
}

\author{
$\checkmark$ Authors \\ vii Conference Committee
}

\section{SESSION 1 IMAGE ACQUISITION}

1033402 Motion blur characterization and compensation for line scan (1D) cameras [10334-1]

1033403 Structural influence of a spatial light modulator on generated wavefronts for specklebased shape measurement [10334-2]

1033404 Robust and efficient modulation transfer function measurement with CMOS color sensors [10334-3]

\section{SESSION 2 SIMULATION}

1033405 Simulated BRDF based on measured surface topography of metal [10334-4]

1033406 Image formation simulation for computer-aided inspection planning of machine vision systems [10334-5]

\section{SESSION $3 \quad$ MULTISPECTRAL INSPECTION}

1033407 Detection of cracks on concrete surfaces by hyperspectral image processing [10334-6]

1033408 Optical determination of material abundances by using neural networks for the derivation of spectral filters [10334-7]

\section{SESSION 4 INSPECTION, MONITORING AND DETECTION}

10334 OA Digital image processing algorithms for automated inspection of dynamic effects in roller bearings [10334-9]

10334 OC Automated stent defect detection and classification with a high numerical aperture optical system [10334-11]

10334 OD Improved maximum likelihood estimation of object pose from 3D point clouds using curves as features [10334-12] 
10334 OE Study of landmarks estimation stability produced by AAM [10334-13]

10334 OF Stereo matching using neighboring system constructed with MST [10334-14]

10334 OG High-reflection microprismatic material as a base for passive reference marks in machine vision metrology applications [10334-15]

$10334 \mathrm{OH} \quad$ A novel sparse-to-dense depth map generation framework for monocular videos [10334-16]

10334 Ol A novel airport extraction model based on saliency region detection for high spatial resolution remote sensing images [10334-17]

10334 OJ Real-time detection of abandoned bags using CNN [10334-18]

10334 OK A novel vehicle tracking algorithm based on mean shift and active contour model in complex environment [10334-19]

$10334 \mathrm{OL}$ Method of measuring linear displacements of objects based on Fresnel diffraction pattern position [10334-20]

10334 OM A novel visual saliency analysis model based on dynamic multiple feature combination strategy [10334-21]

$1033400 \quad$ Automatic 3D inspection metrology for high-temperature objects [10334-23]

$10334 \mathrm{OP} \quad \mathrm{CPU}$ architecture for a fast and energy-saving calculation of convolution neural networks [10334-24]

10334 OQ Pedestrian detection in video surveillance using fully convolutional YOLO neural network [10334-25]

10334 OR Development of optical-electronic system for the separation of cullet [10334-26]

10334 OT Schungite raw material quality evaluation using image processing method [10334-28]

10334 OU Express quality control of chicken eggs by machine vision [10334-29]

10334 OV Distance error correction for time-of-flight cameras [10334-30]

10334 OX Towards automated human gait disease classification using phase space representation of intrinsic mode functions [10334-32] 


\section{Authors}

Numbers in the index correspond to the last two digits of the seven-digit citation identifier (CID) article numbering system used in Proceedings of SPIE. The first five digits reflect the volume number. Base 36 numbering is employed for the last two digits and indicates the order of articles within the volume. Numbers start with 00, 01, 02, 03, 04, 05, 06, 07, 08, 09, OA, OB...0Z, followed by 10-12, 20-2Z, etc.

\author{
Alekhin, Artem A., OR \\ Altmann, Bettina, $\mathrm{OA}$ \\ Anisimov, Andrei G., OG \\ Apel, Uwe, 04 \\ Arbuzova, Evgeniia A., OU \\ Artigas, Roger, OC \\ Aulbach, Laura, 03 \\ Baver, Sebastian, 08 \\ Bergmann, Stephan, 06 \\ Bermudez, Carlos, 0C \\ Beyerer, Jürgen, 06 \\ Bey-Temsamani, Abdellatif, 02 \\ Cadevall, Cristina, OC \\ Cai, Lei, OK \\ $\mathrm{Cao}$, Zhiguo, $\mathrm{OF}, \mathrm{OH}$ \\ Chen, Ran, 00 \\ Cheng, Xu, 00 \\ Chertov, Aleksandr N., OT, OU \\ Czymmek, Vitali, OP \\ Dachsbacher, Carsten, 06 \\ Dantanarayana, Harshana G., OD \\ Farsani, Raziyeh A., 04 \\ Fuersattel, Peter, OV \\ Glebov, Victor, OE \\ Gorbunova, Elena V., OT, OU \\ Grelcke, Michael, OP \\ Gronle, Marc, 05 \\ Haist, Tobias, 05 \\ Han, Liya, 00 \\ Holtorf, Tim, OP \\ Huntley, Jonathan M., OD \\ Hussmann, Stephan, OP \\ Ibañez, Sergi, OC \\ Irgenfried, Stephan, 06 \\ Ivanov, Alexander N., OL \\ Júlio, Eduardo, 07 \\ Knoll, Florian J., OP \\ Knyaz, V. A., OQ \\ Koch, Alexander W., 03 \\ Korotaev, Valery V., OU \\ Krippner, Wolfgang, 08 \\ Laguarta, Ferran, OC \\ Lashmanov, Oleg, $\mathrm{OE}$ \\ Li, Bo, OK \\ Li, Ran, OF \\ Li, Ruibo, $\mathrm{OH}$ \\ Li, Zhongwei, $0 \mathrm{O}$ \\ Lu, Min, 03 \\ $L V$, Jing, $O M$
}

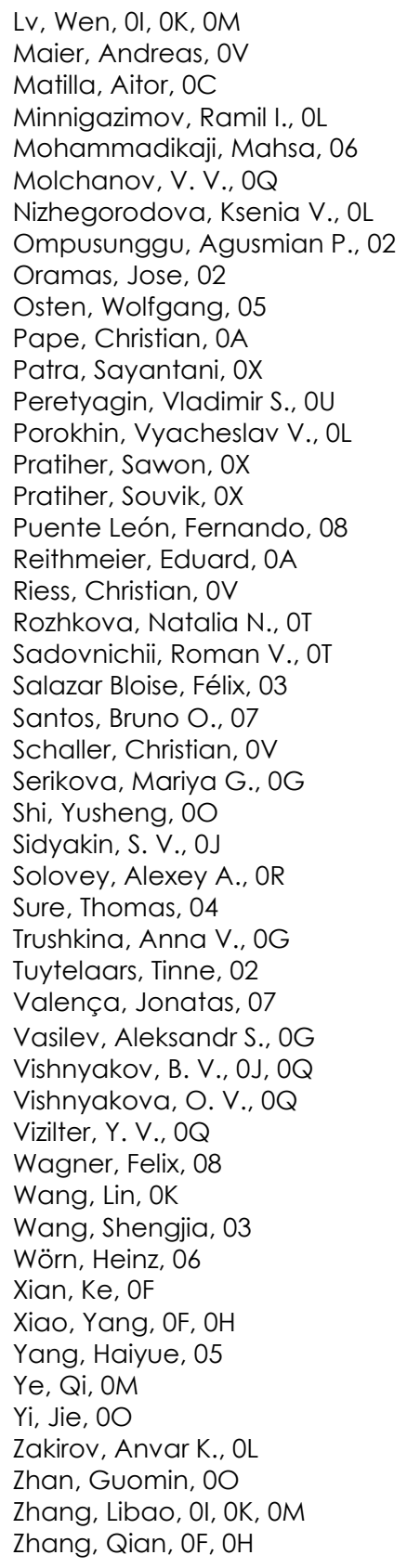


Zhang, Runze, $\mathrm{OH}$

Zhong, Kai, 00

Zhu, Yongchun, 01

Proc. of SPIE Vol. 10334 1033401-6

Downloaded From: https://www.spiedigitallibrary.org/conference-proceedings-of-spie on 26 Apr 2023 Terms of Use: https://www.spiedigitallibrary.org/terms-of-use 


\section{Conference Committee}

Symposium Chair

Wolfgang Osten, Universität Stuttgart (Germany)

Conference Chairs

Jürgen Beyerer, Fraunhofer-Institut für Optronik, Systemtechnik und Bildauswertung IOSB (Germany) and Karlsruher Institut für Technologie (Germany)

Fernando Puente León, Karlsruher Institut für Technologie (Germany)

Conference Programme Committee

Christian Frese, Fraunhofer-Institut für Optronik, Systemtechnik und Bildauswertung (Germany)

Andreas Heinrich, Hochschule Aalen (Germany)

Michael Heizmann, Karlsruher Institut für Technologie (Germany)

Bernd Jähne, Ruprecht-Karls-Universität Heidelberg (Germany)

Thomas Längle, Fraunhofer-Institut für Optronik, Systemtechnik und Bildauswertung (Germany)

Markus Maurer, VITRONIC Dr.-Ing. Stein Bildverarbeitungssysteme GmbH (Germany)

Wolfgang Osten, Universität Stuttgart (Germany)

Felix Salazar, Universidad Politécnica de Madrid (Spain)

Robert Schmitt, Fraunhofer-Institut für Produktionstechnologie (Germany)

Hugo Thienpont, Vrije Universiteit Brussel (Belgium)

Stefan Werling, Duale Hochschule Baden-Würtemberg (Germany)

Ernst Wiedenmann, Serious Enterprises (Germany)

Volker Willert, Technische Universität Darmstadt (Germany)

\section{Session Chairs}

1 Image Acquisition

Jürgen Beyerer, Fraunhofer-Institut für Optronik, Systemtechnik und Bildauswertung (Germany)

2 Simulation

Fernando Puente León, Karlsruher Institut für Technologie (Germany) 
3 Multispectral Inspection

Jürgen Beyerer, Fraunhofer-Institut für Optronik, Systemtechnik und Bildauswertung (Germany)

4 Inspection, Monitoring, and Detection

Fernando Puente León, Karlsruher Institut für Technologie (Germany) 